\title{
Sınıf Öğretmenlerinin Eleştirel Pedagoji İlkelerine Katılım Düzeyleri
}

\author{
Ali Tansu Balc1 ${ }^{1}$, Ayfer Kocabaş ${ }^{2}$ \\ ${ }^{1}$ Eğitim Bilimleri Bölümü, Eğitim Bilimleri Enstitüsü, Ankara Üniversitesi, Ankara, Türkiye \\ ${ }^{2}$ Temel Eğitim Bölümü, Buca Eğitim Fakültesi, Dokuz Eylül Üniversitesi, İzmir, Türkiye
}

Sorumlu Yazar: Ali Tansu Balc1, alitansubalci@gmail.com

Makale Türü: Araştırma Makalesi

Bilgilendirme: $\mathrm{Bu}$ makale, birinci yazarın ikinci yazarın danışmanlığında tamamladığı tez çalışmasına dayalı olarak oluşturulmuştur.

Kaynak Gösterimi: Balcı, A. T., \& Kocabaş, A. (2020). Sınıf öğretmenlerinin eleştirel pedagoji ilkelerine katılım düzeyleri. Eğitimde Kuram ve Uygulama, 16(1), 53-68. doi: 10.17244/eku.638268

\section{The Participation Level of Primary School Teachers to the Critical Pedagogy Principles}

\author{
Ali Tansu Balc1 ${ }^{1}$, Ayfer Kocabaş ${ }^{2}$
}

1 Department of Educational Sciences, Graduate School of Educational Sciences, Ankara University, Ankara, Turkey 2 Department of Elementary Education, Buca Faculty of Education, Dokuz Eylul University, Izmir, Turkey

Corresponding Author: Ali Tansu Balc1, alitansubalci@gmail.com

Article Type: Research Article

Acknowledgement: This article was generated based on the first author's thesis study completed under the guidance of second author.

To Cite This Article: Balcı, A. T., \& Kocabaş, A. (2020). Sınıf öğretmenlerinin eleştirel pedagoji ilkelerine katılım düzeyleri. Eğitimde Kuram ve Uygulama, 16(1), 53-68. doi: 10.17244/eku.638268 


\title{
Sınıf Öğretmenlerinin Eleştirel Pedagoji İlkelerine Katılım Düzeyleri
}

\author{
Ali Tansu Balc1 ${ }^{1}$, Ayfer Kocabaş ${ }^{2}$ \\ ${ }^{1}$ Eğitim Bilimleri Bölümü, Ĕ̆itim Bilimleri Enstitüsü, Ankara Üniversitesi, Ankara, Türkiye \\ ORCID: https://orcid.org/0000-0003-2646-5175 \\ ${ }^{2}$ Temel Eğitim Bölümü, Buca Eğitim Fakültesi, Dokuz Eylül Üniversitesi, İmir, Türkiye \\ ORCID: https://orcid.org/0000-0002-5566-212X
}

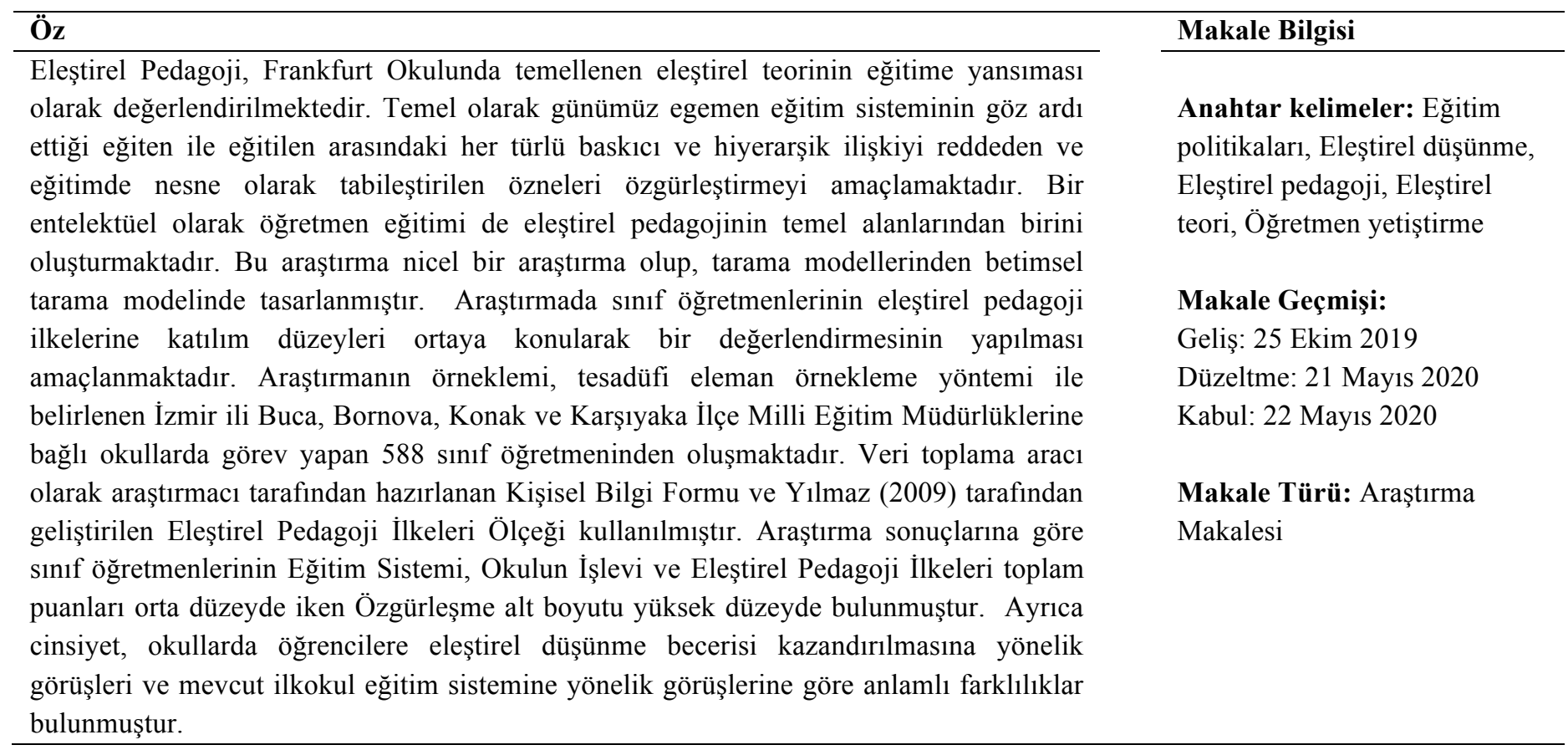




\section{The Participation Level of Primary School Teachers to the Critical Pedagogy Principles}

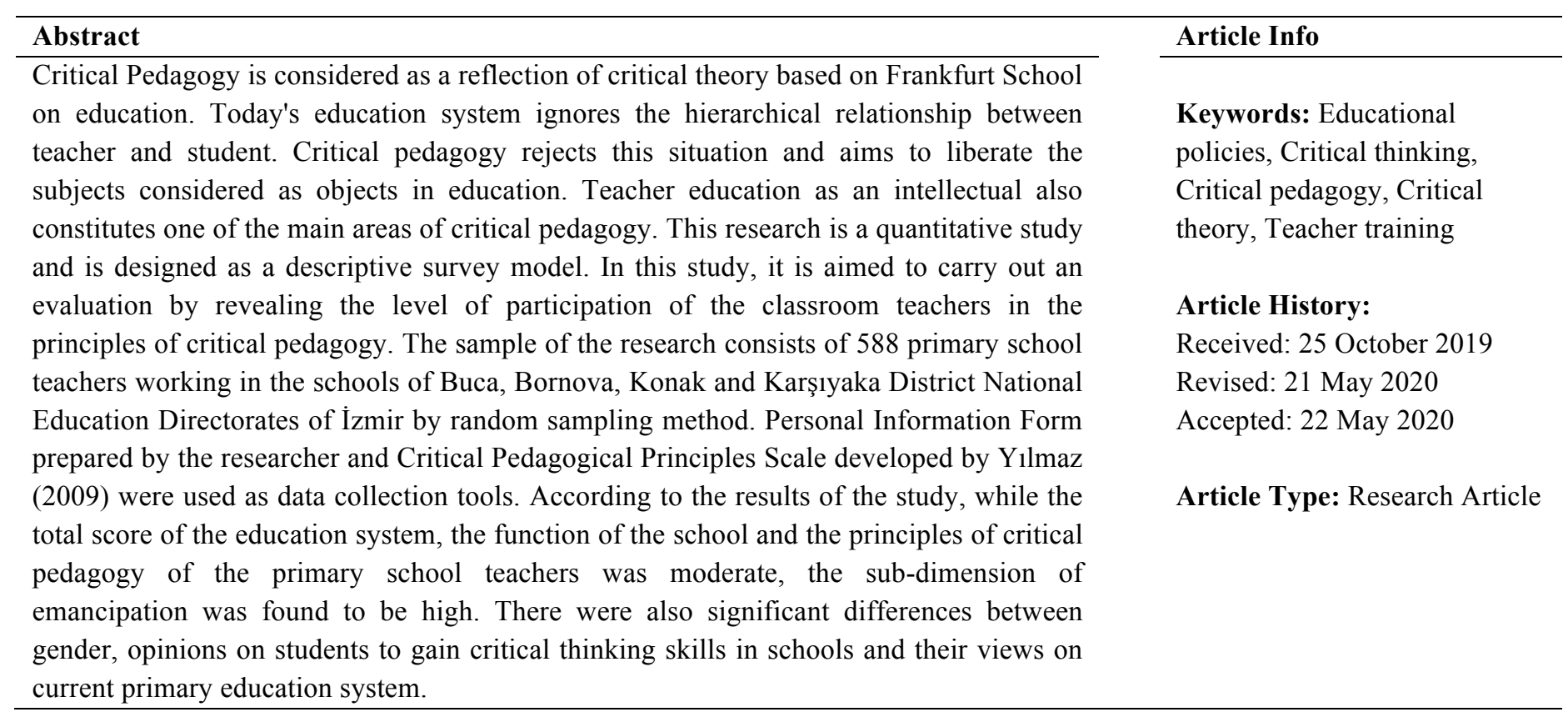




\section{Extended Summary}

\section{Introduction}

Critical Pedagogy is considered as the reflection of critical theory based on education in Frankfurt School. It aims to liberate the subjects that are rejected as the object in education and reject all kinds of oppressive and hierarchical relations between the educator and the educated, which are ignored by today's dominant education system (McLaren, 2011). Critical pedagogy is an educational philosophy that systematically discusses current educational problems. In this interpretation, there is a multi-layered structure such as the relationship between education and social institutions, the relationship between education institutions, industry-capital-trade, and the relationship between curriculum and ideology (Y1lmaz \& Altınkurt, 2011). Teacher training as an intellectual is also one of the key areas of critical pedagogy.

If a teacher does not have a critical stance, it would not be appropriate to expect that teacher to raise critical thinkers. Moreover, this situation is not limited to teachers. If students are asked to think critically, teachers, administrators and inspectors should be able to think critically and creatively (Bakioğlu \& Hesapçığlu, 1997). Teachers should be able to analyze not only the acceptor of externally directed change, but also their own teaching and achievement. So, the role of the teacher as teachers and other subjects of education to be critical can affect the student. In addition, all subjects of education can be critical and have a direct and positive effect on education (Edwards Jr, 2009).

\section{Purpose}

In this study, the level of participation of classroom teachers in critical pedagogy principles is put forward and evaluated according to their gender, their opinions about providing students with critical thinking skills in schools and their opinions about the current primary education system. In this way, it is aimed to reveal how critical the teachers who will educate critical thinkers look at their education systems.

According to this aim, the problem sentence of the research is determined as follows: To what extent the classroom teachers' participation in the principles of critical pedagogy; Does this level show significant differences according to their gender, their opinions on providing students with critical thinking skills in schools and their views on the current primary education system?

\section{Method}

The research was designed in the descriptive scanning model of quantitative research method. In this research, it is aimed to make an evaluation by revealing the participation levels of classroom teachers in critical pedagogical principles. The sample of the study consists of classroom teachers working in schools affiliated to Buca, Bornova, Konak and Karşıyaka District National Education Directorates in İzmir. 588 classroom teachers were selected by random sampling method to form the study group of the study.

The Personal Information Form prepared by the researcher and the Critical Pedagogical Principles Scale developed by Yilmaz (2009) were used as data collection tools. The scale consists of 31 five-point Likert-type items and consists of three sub-dimensions: "Education System, Functions of the School and Liberation". In the original scale, Cronbach's Alpha reliability coefficient was 0.75 for the whole scale; 0.88 for the education system subdimension; 0.78 for the function of the school sub-dimension; for the liberation sub-dimension, it is 0.61 . Subdimension load values of the items in the original form of the scale ranged from 0.31 to 0.80 . The total variance explained by the whole scale is $40 \%$.

For this study, Cronbach's Alpha reliability coefficient and factor load values of the scale were re-examined. Accordingly, Cronbach's Alpha reliability coefficient for the whole scale was $0.72 ; 0.76$ for the sub-dimension of the education system; 0.63 for the sub-dimension function of the school; and 0.65 for the sub-dimension of liberation. Factor load values of the scale vary between 0.31 and 0.65 . The factor load value of the $19^{\text {th }}$ item in the education system sub-dimension was found to be 0.14 . In this case, it can be said that all items except for $19^{\text {th }}$ item provide a strong factor structure. In order not to disturb the original form of the scale, $19^{\text {th }}$ item was not removed from the scale.

\section{Findings}

1. There is a significant difference in the School Function sub-dimension and the total score of Critical Pedagogical Principles according to the gender of classroom teachers. This difference is in favor of male teachers in both dimensions. In addition, the classroom teachers' Education System, School's Function and Critical Pedagogical Principles were moderate; the liberation sub-dimension was found to be high.

2. According to the opinions of the classroom teachers towards providing students with critical thinking skills in schools, the average scores of classroom teachers who think that students do not acquire critical thinking skills in schools in all dimensions are higher than the average scores of teachers who think that they have acquired critical 
thinking skills. There is also a significant difference in the Education System and the Functions of the School and Critical Pedagogical Principles. These differences are as follows:

2.1. Classroom teachers who think that students do not acquire critical thinking skills in schools are more critical to education systems than classroom teachers who think that they are acquired and partially acquired.

2.2. Classroom teachers who think that students do not acquire critical thinking skills in schools are more critical to the functions of the school than classroom teachers who think that they are acquired or partially acquired.

2.3. Classroom teachers who think that students do not acquire critical thinking skills in schools show more participation in the principles of critical pedagogy than classroom teachers who think that they are acquired or partially acquired.

3. The majority of classroom teachers have negative views on existing primary education systems. In addition, there are significant differences in the Education System and the Function of the School and the Critical Pedagogical Principles according to the opinions of the classroom teachers about the current primary education system. These differences are as follows:

3.1. Classroom teachers who do not give any positive opinion about the education system are more critical to the education systems than the ones having very positive, partially positive and not much positive opinions.

3.2. Classroom teachers who have partially positive opinions about the education system are less questioning about the functions of the school than the ones having not given very positive opinions and never give positive opinions.

3.3. As in the sub-dimension of Education System and Function of School, there is a significant difference between classroom teachers who have negative opinions about education system and classroom teachers who have positive opinions in favor of classroom teachers who have negative opinions. Accordingly, classroom teachers who have negative opinions about the education system are more involved in critical pedagogical principles. 


\section{Giriş}

Eğitim sürecinden beklenen soru soran, sorgulayan ve dünyayı algılamaya çalışan bireyler yetiştirmektir. Sistemli bir şekilde soru sorma ve cevap arama süreci aynı zamanda bilimsel bilginin de temelini oluşturmaktadır. Merak ise bilimsel düşüncenin itici gücüdür. Hiç kuşkusuz sorma ve sorgulama eylemi, içerisinde eleştirel düşünmeyi de barındıran bir süreçtir ancak burada eleştirel düşünme -algılandığ 1 gibi- tek başına negatif/yıkıcı bir eleştiriden ibaret değildir. İçerisinde olumlu ya da olumsuz düşüncelerin ifade edildiği ve genellikle eleştirilen her neyse yerine bir alternatifinin konulduğu ve/veya konulmaya çalışıldığı aktif bir düşünme eylemidir (Passmore, 1991).

Eğitim üzerine düşünceler temelde çeşitli eğitim felsefeleri üzerinden şekillenmektedir. Bunun yanında eğitim aynı zamanda sosyolojik açıdan da değerlendirilmektedir. Eleştirel pedagoji ise felsefi açıdan eleştirel eğitim felsefesine; sosyolojik açıdan ise eleştirel teoriye dayanmaktadır (Tezcan,2013). Cevizci'ye (2014) göre onu diğer eleştirel eğitim felsefesinden ayıran ise somut ve önemli sonuçları bulunan bir eğitim felsefesi olması ve kendine özgü bir eğitim anlayışı ve kuramıyla ortaya çıkmasıdır. Tüm bunların yanında onun en büyük avantajı ise Paulo Freire gibi, 20. yüzyılın son çeyreğine damgasını vurmuş büyük bir eğitimci tarafindan temsil ediliyor olmasıdır. 20. yüzyılın başında John Dewey eğitime ne kadar büyük etki yaptıysa, Freire'nin etkisi için de aynı şeyleri söylemek mümkündür (Breault, 2003; Porfilio, 2009; aktaran Cevizci, 2014).

Frankfurt Okulunun (eleştirel teori) eleştirel pedagoji üzerine etkileri ise temelde Marksizm ve pozitivizm eleştirisi üzerinedir. Ancak eleştirel teori özünde Marksist bir yaklaşım olarak görülmekle birlikte aynı zamanda Marksizm eleştirilerini barındırmakta; pozitivizmi eleştirmekle birlikte pozitivist bilimleri yok saymamaktadır. Bu bağlamda eleştirel teori diyalektik sosyal bilim anlayışını savunmaktadır (Durdu, 2006). Bir başka deyişle eleştirel teori, söz konusu toplumsal dünya olduğunda, bilimsel bilgi ancak eleştiri yoluyla üretilebilir iddiasında bulunmaktadır. Dolayısıyla o, kendisini eleştirel sosyal bilim olarak da adlandırır (Balkız, 2004).

Eleştirel pedagoji felsefi ve sosyolojik yapısı gereği eğitimin birçok alanı ile ilgilenmektedir. Bunlar arasında öğretmen eğitimi, yabancı dil öğretimi, uluslararası çalışmalar, öğrenme-öğretme, yönetim, postmodernite, teknoloji ve ayrımcılık sayılabilir (Yılmaz \& Altınkurt, 2011). Bu araştırmada daha çok eleştirel pedagojinin öğretmen eğitimi ve öğrenme-öğretme boyutları üzerinde durulmaktadır.

Eleştirel pedagojik açıdan mevcut durumda eğitim üretenler için kar, eğitim hizmetinden yararlananlar için geleceğe yatırım olmakta, buradan da bireylerin geleceğe yatırım için bugünün maliyetini yüklenmesi söz konusu olmaktadır. Kısaca, eğitim "karlılık", "verimlilik", "rasyonellik" ölçütlerine göre ele alınıp maliyeti yüklenildiği ölçüde yararlanılabilen alınıp satılabilen bir metaya dönüşmektedir. "Bilgi toplumu”na, "öğrenen toplum”a, ekonomik ve teknolojik gelişmelere ayak uydurmada eğitime önemli bir görev yüklenmekte ve bu durum eğitime verilen önemin artmasına, buna paralel olarak da eğitimin sermaye için yeni yatırım alanı, kar getirici bir sektör olarak algılanması durumu ortaya çıkarmaktadır (Ercan, 1998). Apple (2006, 2009)'a göre devlet bugün kendi vatandaşını basit bir tüketici, dünyayı ise kocaman bir süpermarket olarak görmektedir. Benzer şekilde Giroux (2009) da gençlerin eleştiren özneler olmaktan ziyade giderek tüketen öznelere dönüştürüldüklerini belirtmektedir. Örnekler çoğaltılabilir ancak temel soru, eğitim yönetim ve içeriğinin belirlenmesinde bireyi mi esas alacağız yoksa piyasa koşullarını mı olmalıdır. Mevcut durumda öğrenci (birey) temelli bir eğitimden söz edilirken aslında arka planda piyasanın isteklerine göre bir eğitim söz konusudur. Sağıroğlu (2008)'na göre eğitimin bireyin kendini gerçekleştirdiği bir süreç olarak işlemesi ve özgürleştirici boyutunun açığa çıkarılması için eğitimin piyasa değerlerinden kurtarılması gerekmektedir. Başka bir ifadeyle eğitim mevcut sosyal yapıyı ve politik düzeni koruyup yeniden üretmeye (Passeron \& Bourdieu, 2015) mi yoksa dönüştürmeye yönelik mi olmalıdır sorusu eğitim felsefesinin politik boyutu içinde karşımıza çıkmaktadır (Cevizci, 2014). Bu anlamda eğitim algımıza dair eleştirel yaklaşım ihtiyaç halini almıştır. Söz konusu eleştirel yaklaşım, eleştirel olma ile ilgili belli olguları öğrenmiş olmaktan sadece mantıksal olarak değil deneysel olarak da farklıdır (Passmore, 1991). Eğitim üzerine eleştiriler, Eleştirel Pedagoji ile başlamamakla birlikte ilk çağlardan günümüze eğitim her zaman tartışılagelmiştir ancak eleştirel pedagoji bütün bu eleştirel bakış açılarının sistemli bir hal alması durumu olarak görülmektedir.

Gelecek kuşakları yetiştirecek bir öğretmen için günlük rutinlerle ve ayrıntılarla ilgilenmek tek başına yeterli değildir. Her öğretmen, "iyi” bir birey ve buna bağlı toplumu yaratmada eğitimin önemli bir rolü olduğunu bilir ve bu süreçte üstlendiği rolün gereklerini düşündüğünde salt uygulamanın ötesine geçerek bu uygulamaların dayandığı kuramları incelemesi gerekmektedir. Öğretim kuram ve uygulamanın dikkatli bir sentezini gerektirir. Uygulamasız bir kuram yararsızdır, kuram ile desteklenmeyen uygulama ise hedefine ulaşmaz (Gutek, 2006). Pekâlâ, öğretmenler uygulanagelen kuramlara ne kadar eleştirel bakabilmekte ve uygulamakla yükümlü olduğu kuramları ne kadar eleştirebilmekte ya da eleştirebilmekte midir? Başka bir deyişle çocukların eleştirel düşünme becerilerini kazanmasında onlara rehberlik edecek olan öğretmenin kendisi, uygulayıcısı olduğu eğitim sistemini ne kadar eleştirebilmektedir ya da öğretmenin sistemi eleştirmesine gerek var mıdır? Eğer öğretmenin sadece uygulayıcı olması yeterli görülüyorsa, gerekli eğitimi alan öğretmenler verilen kuramları sorgulamadan uygulamada bir sorun yaşamayacaktır. Ancak öğretmeni bir entelektüel (Gramsci, 2014) olarak ele aldığımızda ise sadece uygulayıcı olması onu entelektüellikten uzaklaştıracaktır. 
Eğer bir öğretmen eleştirel bir duruşa sahip değilse, o öğretmenden eleştirel düşünen bireyler yetiştirmesini beklemek yerinde olmayacaktır. Kaldı ki bu durum sadece öğretmenlerle de sınırlı değildir. Eğer öğrenciler eleştirel düşünsün isteniyor ise öğretmen, yöneticiler, müfettişler de eleştirel ve yaratıcı bir şekilde düşünebilmelidir. Öğretmenler sadece dışarıdan yönlendirilen değişimin kabullenicisi değil, aynı zamanda kendi öğretimini ve başarısını analiz edebilmelidir (Bakioğlu \& Hesapçığlu, 1997). O halde rol modeller olarak öğretmenin ve eğitimin diğer öznelerinin de eleştirel olması öğrenciyi de etkileyebilmektedir. Bunun yanında eğitimin bütün öznelerinin eleştirel olabilme halleri ise eğitimi doğrudan ve pozitif yönde etkileyebilmektedir.

Bir çocuğa eleştirel olma nasıl öğretilir, birinin eleştirel düşünme becerisini kazandığını nasıl anlayabiliriz, bu beceri -eğer bir beceri ise- müfredat yoluyla nasıl kazandırılır, eleştirel olma ile ilgili olgu aktarımı bireyi eleştirel yapar mı (Passmore, 1991) gibi sorular eleştirel düşünmeyi çok boyutlu tartışmamız gerektiğini düşündüren sorulardır. Eleştirel düşünme mevcut sistemde öğrencilere ne kadar kazandırılabilir, sınırları çizilmiş bir eleştiri kavramı gerçekten de insanları eleştirel birer düşünür yapabilir mi yoksa bu bir yanılsama mıdır? Bu noktada eleştirel düşünme konusunda en önemli referans noktalarından biri de eleştirel pedagojidir. Ancak eleştirel düşünme üzerine yapılan çalışmaların neredeyse hiçbirinde eleştirel pedagojiden söz edilmemektedir (Balcı \& Kocabaş, 2018).

Eleştirel pedagoji köklerini Frankfurt Okulu'ndan alan ve eleştirel teoriye dayanan bir eğitim felsefesidir. Temel olarak geleneksel eğitim sistemine eleştiriler getirmekte ve alternatifler sunmaktadır. Bu anlamda eleştirel pedagoji, eğiten ile eğitilen arasındaki her türlü baskıcı ve hiyerarşik ilişkiyi ortadan kaldırmak ve eğitimde nesne olarak öngörülen öğrencileri yani özneleri özgürleştirmek istemektedir (İnal, 2014). Eleştirel pedagoji günümüz eğitim sorunlarını sistematik olarak tartışan bir eğitim felsefesidir. Bu yorum içerisinde eğitim ile sosyal kurumlar arasındaki ilişki, eğitim kurumları sanayi-sermaye-ticaret ilişkisi, müfredat-ideoloji ilişkisi gibi çok katmanlı bir yapı söz konusudur (Yıldırım, 2013).

Eleştirel pedagojinin öncülerinden olan Freire (2003, 2014)'nin bankacı eğitim modelinde ise öğrenciler yatırım nesneleri, öğretmenler ise yatırımcıdır. Freire'nin bu görüşü davranışçı kurama getirilen eleştirilerle benzerlik göstermektedir. Buna göre öğrenciler bilgiyi alan, ezberleyen öğretmenler ise aktaran konumundadır. Ancak Freire bu durumda tümden sistemi sorgulamakta ve yanlış yoldaki sistemde, yaratıcılık, dönüşüm ve bilgi yoksunluğu yüzünden rafa kaldırılanın bizzat insanlar olduğunu düşünmektedir. Bu noktada Freire'nin önerisi problem tanımlayıcı eğitimdir. $\mathrm{Bu}$ anlayışta insanlar içinde bulundukları durumu ve dünyada var olma tarzlarını eleştirel olarak kavrarlar ve dünyayı durağan bir gerçeklik olarak değil süreç içerisinde dönüşen bir gerçeklik olarak anlamaya başlarlar. Bankacı eğitim gerçekliği mitleştirirken problem tanımlayıcı eğitim bizzat gerçekliğin üzerine gitmektedir. Öğrenci "iki artı iki dört eder" ya da "Türkiye'nin başkenti Ankara'dır"ı öğrenirken iki artı ikinin gerçeklikte ne olduğunu anlamadan ya da başkentin gerçek anlamını bilmeden ezberlemektedir. Burada bir mitleştirme söz konusudur ki bu da ezberci bir eğitimi doğurur. Etkili bir eğitim ise gerçekliği anlamakla mümkün olacaktır. Passmore (1991) da benzer bir şekilde, bir sürücü kursunda iyi bir sürücü eğitimi verilebileceğini söyler ancak kurs kitabında yer alan sorulara doğru cevaplar veren öğrencinin iyi bir sürücü olduğunu söylemek mümkün değildir zira burada öğrencinin gerçekliği anlayabilmesi için onu yaşaması gerekecektir. Bu eğitim modeli bilgi aktarımından değil, alg1 ediminden oluşur. Otorite yoktur ve hiç kimse diğerine ders veremez. Öğrenciler ve öğretmenler diyalog içindedirler ve eleştirel araştırma ortakları olurlar (Tezcan, 2013). Bu yaklaşımın özü toplumu ve dünyayı eleştirerek dönüştürmeyi amaçlayan bilinç yükseltme çabasıdır (Gök, 1999).

Eleştirel pedagojinin alanyazına kazandırdığı önemli başlıklardan biri de praksis kavramıdır. Aslında öğrencilere kazandırmaya çalıştığımız eleştirel düşünme bilincini bir dünyayı algılama biçimine dönüştüremememizin nedenlerinden biri praksis eksikliğidir. Praksis düşünceyi eyleme dönüştürebilme, eylem içerisinde düşünme ve bunu bir felsefe haline getirebilmektir (Freire, 2003). Öğrencilerin praksiste olan eksikliği günümüz eğitim sisteminde önemli sorunlardan biridir. Okulda müfredat yoluyla öğrencilere kazandırmaya çalıştığımız eleştirel düşünme bilincini, öğrenciler günlük hayatta uygulayamaz durumdadır. Öyle ki bir öğrenci her ne kadar eleştirel bir tutuma sahip olsa bile söz konusu eleştiri okul müdürü ya da öğretmen ise bu öğrencinin gerçekçi bir eleştiri yapabilmesinin önü bizzat bu yapılar tarafindan engellenmekte ve olumsuz yaptırımlar uygulanabilmektedir. Böyle olunca da her zaman bir yanı eksik kalmış bir eleştirel düşünme ortaya çıkmaktadır. Var olan durum da bunu göstermektedir (McLaren, 2011).

McLaren'e (2011) göre eleştirel düşünme tartışmasında, eleştirel kavramı sürekli yenilenerek ve dikkatsiz kullanılarak etkisizleştirilmektedir. Kavram, siyasal ve kültürel boyutlardan uzaklaştırarak, salt analitik bir düşünme becerisine dönüştürülmüştür (Tezcan, 2013). Eleştiri ancak tarihsel ve toplumsal bağlam içinde ele alındığı müddetçe mümkündür. $\mathrm{Bu}$ nedenle yapılması gereken, mevcut eleştirel yaklaşımı toplumsal koşulları içinde yeniden yorumlamaktır. Bu da eleştirel-diyalektik yöntemle kavram ve gerçeklik arasındaki ilişkinin sürekli olarak yeniden ele alınması ile mümkün olacaktır (Gülenç, 2010). Sonuç olarak eleştirel düşünme becerisini bir kavram; öğrenci, öğretmen adayı ve öğretmenlerin eleştirel düşünme düzeylerinin düşüklüğünü bir gerçeklik olarak ele aldığımızda, yapılması gereken kavram ve gerçeklik arasındaki ilişkini yeniden ele alınması ve bunu yaparken de eleştirel pedagojiden yararlanmanın gerekli olduğu düşünülmektedir. Aksi durumda eleştirel düşünme becerisinin öğrencilere kazandırılması için kullanılması gereken öğretim yöntemleri üzerinden sığ bir tartışma yürütülmüş olacaktır. 
$\mathrm{Bu}$ araştırmada sınıf öğretmenlerinin eleştirel pedagoji ilkelerine katılım düzeylerinin ortaya konularak cinsiyetleri, okullarda öğrencilere eleştirel düşünme becerisi kazandırılmasına yönelik görüşleri ve mevcut ilkokul eğitim sistemine dair görüşlerine göre değerlendirmesi yapılmaktadır. Bu sayede eleştirel düşünen bireyleri yetiştirecek olan öğretmenlerin, eğitim sistemlerine ne kadar eleştirel baktıklarının ortaya konulması amaçlanmaktadır.

\section{Problem Cümlesi}

$\mathrm{Bu}$ araştırmada problem cümlesi şu şekilde belirlenmiştir: Sınıf öğretmenlerinin eleştirel pedagoji ilkelerine katılımları ne düzeydedir? Problem cümlesinden hareketle, araştırmada 3 adet alt problem belirlenmiştir. Bunlar:

1. Sınıf öğretmenlerinin eleştirel pedagoji ilkelerine katılım düzeyleri cinsiyetlerine göre anlamlı bir farklılık göstermekte midir?

2. Sınıf öğretmenlerinin eleştirel pedagoji ilkelerine katılım düzeylerine göre okullarda öğrencilere eleştirel düşünme becerisi kazandırılmasına yönelik görüşleri anlamlı bir farklılık göstermekte midir?

3. Sınıf öğretmenlerinin eleştirel pedagoji ilkelerine katılım düzeylerine göre mevcut ilkokul eğitim sistemine dair görüşleri anlamlı bir farklılık göstermekte midir?

\section{Araştırmanın Deseni}

Yöntem

Araştırma nicel araştırma yöntemleri genel tarama modellerinden betimsel tarama modelinde tasarlanmıştır. Tarama modelleri geçmişte ya da şu anda var olan bir durumu var olduğu şekliyle betimlemeyi amaçlayan araştırma modeli olup (Karasar, 2013), bir grubun belirli özelliklerini olabildiğince tam ve dikkatli bir şekilde belirlemeyi amaçlamaktadır. (Büyüköztürk, Çakmak, Akgün, Karadeniz \& Demirel, 2013).

\section{Çalışma Grubu}

Çalışma grubu, ulaşılabilen evrendir. Araştırmacının, ya doğrudan gözleyerek ya da ondan seçilmiş bir örnek küme üzerinde yapılan gözlemlerden yararlanarak, hakkında görüş bildirebileceği evren çalışma evrenidir. Pratikte araştırmalar, çalışma grubu üzerinde yapılmakta olup sonuçların da, yalnızca bu sınırlı evrene genellenmesi kaçınılmazdır. O halde evreni tanımlama ve sınırlama, aslında çalışma grubunu belirleme için yapılmaktadır (Smith, 1975, aktaran Karasar, 2013).

Araştırmanın evreni, 2014-2015 eğitim-öğretim yılında İzmir ili Buca, Bornova, Karşıyaka ve Konak İlçe Milli Eğitim Müdürlüklerine bağlı okullarda görev yapan sınıf öğretmenlerinden oluşmaktadır. Araştırmanın çalışma grubunu oluşturmak için tesadüfi eleman örnekleme metodu ile 588 sınıf öğretmeni seçilmiştir. Çalışma grubunun demografik özellikleri Tablo 1'de sunulmaktadır.

Tablo 1. Çalışma Grubunun Demografik Özellikleri

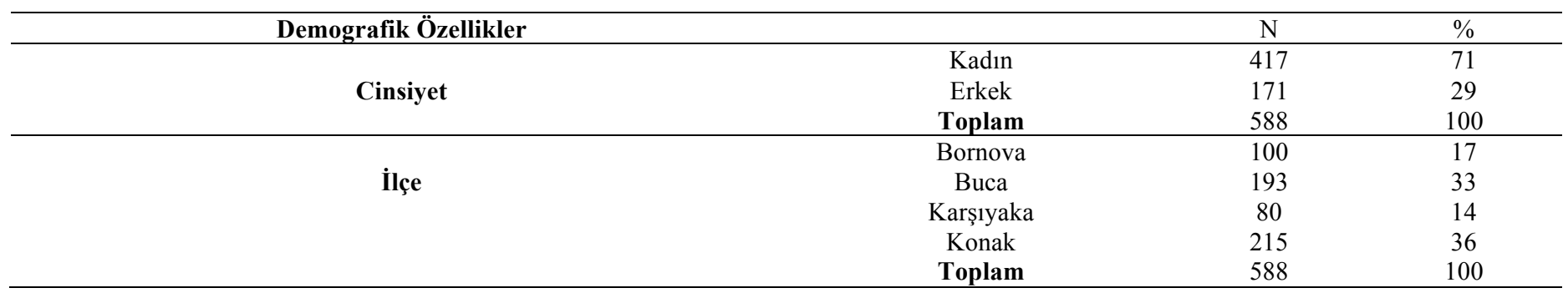

\section{Veri Toplama Araçları}

Araştırmada, çalışma grubunun demografik özelliklerini belirlemek için araştırmacı tarafından geliştirilen kişisel bilgi formu, eleştirel pedagoji ilklerine katılımı değerlendirmek için Yılmaz (2009) tarafından geliştirilen Eleştirel Pedagoji İlkeleri ölçeği kullanılmıştır.

Kişisel Bilgi Formu: Araştırmanın amacına ve alt problemlerine uygun olarak seçilen değişkenlere ait cinsiyet, eleştirel düşünme becerisi kazandırılmasına yönelik görüş ve mevcut ilkokul eğitim sistemine dair görüşü çalışma grubundan elde etmek amacıyla, araştırmacılar tarafından geliştirilmiştir. Ayrıca üç farklı uzman görüşü alınarak forma son şekli verilmiştir.

Eleştirel Pedagoji İlkeleri Ölçeği: Yılmaz (2009) tarafından geliştirilen ölçekte, beşli likert tipi 31 madde bulunmakta ve "Eğitim Sistemi, Okulun İşlevleri ve Özgürleşme" olmak üzere üç alt boyuttan oluşmaktadır. Birinci boyut olan "Eğitim Sistemi Alt Boyutu”nda 15 madde bulunmaktadır. İkinci alt boyut olan "Okulun İşlevleri Alt Boyutu"nda 11 madde bulunmaktadır. Üçüncü alt boyut olan "Özgürleşme Alt Boyutu"nda 5 madde bulunmaktadır. Ölçek 1- 
Kesinlikle Katılmıyorum, 2-Katılmiyorum, 3-Orta Derece Kat1liyorum, 4-Kat1lyorum ve 5-Kesinlikle Kat1liyorum şeklinde yanıtlanmaktadır. Ölçekte yer alan 12 madde $(4,5,6,7,8,9,10,12,14,16,18,22)$ ters kodlanmaktadır. Yanıtlayıcıların ölçeğe verdikleri yanıtlar alt boyutlar bazında değerlendirilebildiği gibi ölçekten bir toplam puan da elde edilebilmektedir. Katılımcıların ölçekten aldıkları puanın yükselmesi eleştirel pedagoji ile ilgili ilkelere katılma düzeylerinin yükseldiğini, düşmesi ise düştüğünü göstermektedir. Ölçeğin orijinalinde Cronbach's Alpha güvenirlik katsayısı ölçeğin tamamı için 0,75 ; eğitim sistemi alt boyutu için 0,88 ; okulun işlevi alt boyutu için 0,78 ; özgürleşme alt boyutu için ise 0,61 'dir. Ölçeğin orijinal formunda yer alan maddelerin alt boyut yük değerleri 0,31 ile 0,80 arasında değişmektedir. Ölçeğin tamamının açıkladığı toplam varyans \% 40’tır.

Bu çalışma için ölçeğin Cronbach's Alpha güvenirlik katsayısı ve faktör yük değerlerine tekrardan bakılmıştır. Buna göre ölçeğin tamamı için Cronbach's Alpha güvenirlik katsayısı 0,72; eğitim sistemin alt boyutu için 0,76; okulun işlevi alt boyutu için 0,63 ; özgürleşme alt boyutu için ise 0,65 bulunmuştur. Ölçeğin faktör yük değerler ise 0,31 ile 0,65 arasında değişmektedir. Eğitim sistemi alt boyutunda yer alan 19. maddenin faktör yük değeri 0,14 bulunmuştur. Bu durumda 19. madde dışında diğer tüm maddelerin güçlü bir faktör yapısı sağladığı söylenebilir. Ölçeğin orijinal formunu bozmamak adına 19. madde ölçekten çıkarılmamıştır.

\section{Verilerin Analizi}

Araştırmada kullanılacak analizlere geçmeden önce verilerin normal dağılım gösterip göstermediğine bakılmıştır. Bunun için Kolmogorov-Smirnov analizi, aritmetik ortalama, mod, medyan değerleri ile çarpıklık ve basıklık değerlerine bakılarak verilerin normal dağılım gösterdiği tespit edilmiştir. Sınıf öğretmenlerinin kişisel bilgi formunda yer alan değişkenlere göre Eleştirel Pedagoji İlkelerine katılımları arasında anlamlı farklılık olup olmadığına bakmak için değişkenlerin madde sayılarına göre t Testi ya da Anova Testi uygulanmıştır. Madde sayısı iki olan değişkenler için t Testi, ikiden fazla olanlar için Anova Testi uygulanmıştır. Anova Testi sonuçlarında anlamlı farklılık var ise bu farklılığın hangi gruplardan kaynaklandığını öğrenmek için Levene Testi sonuçlarına göre varyanslar homojen bir yapıda ise Scheffe, heterojen bir yapıda ise Games-Howell testi sonuçları dikkate alınmıştır.

\section{Bulgular}

Bu bölümde problem cümlesi ve buna bağlı alt problemlere uygun olarak sınıf öğretmenlerinin eleştirel pedagoji ilkelerine katılımları ile ilgili toplanan verilerin istatistiksel analiz sonuçlarından elde edilen bulgular sunulmaktadır.

\section{Birinci Alt Probleme İlişkin Bulgular ve Yorumlar}

Araştırmanın birinci alt problemi "Sınıf öğretmenlerinin eleştirel pedagoji ilkelerine katılım düzeyleri ile cinsiyetleri arasında anlamlı bir farklılık bulunmakta mıdır?" şeklinde belirlenmişti. Tablo 2'de sınıf öğretmenlerinin cinsiyetlerine göre Eleştirel Pedagoji İlkelerine katılımları incelenmiştir.

Tablo 2. Sınıf öğretmenlerinin cinsiyetlerine göre eleştirel pedagoji ilkeleri katılımları $t$ testi sonuçları

\begin{tabular}{|c|c|c|c|c|c|c|}
\hline Alt Boyutlar & Cinsiyet & $\mathbf{n}$ & - & Ss. & $t$ & $\mathbf{p}$ \\
\hline \multirow{3}{*}{ Ĕgitim Sistemi } & Kadın & 417 & 46,41 & 8,70 & $-1,305$ & 0,192 \\
\hline & Erkek & 171 & 47,47 & 9,51 & & \\
\hline & Toplam & 588 & 46,72 & 8,95 & & \\
\hline \multirow{3}{*}{ Okulun İşlevi } & Kadın & 417 & 34,64 & 5,24 & $-3,470$ & $\mathbf{0 , 0 0 1}$ * \\
\hline & Erkek & 171 & 36,40 & 6,36 & & \\
\hline & Toplam & 588 & 35,15 & 5,64 & & \\
\hline \multirow{3}{*}{ Özgürleşme } & Kadin & 417 & 20,54 & 2,85 & 0,789 & 0,430 \\
\hline & Erkek & 171 & 20,33 & 3,46 & & \\
\hline & Toplam & 588 & 20,48 & 3,04 & & \\
\hline \multirow{3}{*}{$\begin{array}{l}\text { Eleştirel Pedagoji } \\
\text { İlkeleri Toplam }\end{array}$} & Kadin & 417 & 101,60 & 11,42 & $-2,403$ & $0,017 *$ \\
\hline & Erkek & 171 & 104,20 & 13,11 & & \\
\hline & Toplam & 588 & 102,35 & 11,98 & & \\
\hline
\end{tabular}

$\mathrm{p}<0,05$

Tablo 2'de sınıf öğretmenlerinin cinsiyetlerine göre eleştirel pedagoji ilkelerine katılım düzeyleri gösterilmektedir. Buna göre sınıf öğretmenlerinin eğitim sistemi $(-=47,47)$, okulun işlevi $(-=35,15)$ ve eleştirel pedagoji ilkelerine katılımları $(-=102,35)$ orta düzeyde iken özgürleşme $(-=20,48)$ alt boyutuna katılımları yüksek düzeyde bulunmuştur. Ayrıca öğretmenlerin cinsiyetlerine göre Okulun İşlevi $(\mathrm{p}=0,001<0,05)$ alt boyutu ve Eleştirel Pedagoji İlkeleri $(\mathrm{p}=0,017<0,05)$ toplam puanda anlamlı farklılık bulunmuştur. Söz konusu farklılık her iki boyutta da erkek öğretmenler lehine olmaktadır. Bu durum erkek sınıf öğretmenlerinin kadın sınıf öğretmenlerine göre okulun işlevlerine daha eleştirel baktığı ve eleştirel pedagoji ilkelerine daha fazla katılım gösterdiği şeklinde yorumlanabilir. 


\section{İkinci Alt Probleme İlişkin Bulgular ve Yorumlar}

Araştırmanın ikinci alt problemi "Sınıf öğretmenlerinin eleştirel pedagoji ilkelerine katılımları ile okullarda öğrencilere eleştirel düşünme becerisi kazandırılmasına yönelik görüşleri arasında anlamlı bir farklılık bulunmakta mıdır?" şeklinde ifade edilmiştir. Buna göre Tablo 3'de sınıf öğretmenlerinin okullarda öğrencilere eleştirel düşünme becerisi kazandırılmasına yönelik görüşlerine göre eleştirel pedagoji ilkelerine katılımlarında anlamlı bir farklılık olup olmadığına bakılmıştır. Bununla ilgili Anova Testi sonuçları aşağıda yer almaktadır.

Tablo 3. Sınıf öğretmenlerinin okullarda eleştirel düşünme becerisi kazandırılmasına yönelik görüşlerine göre eleştirel pedagoji ilkelerine katılımları Anova Testi sonuçları

\begin{tabular}{|c|c|c|c|c|c|c|}
\hline Alt Boyutlar & $\begin{array}{c}\text { Okullarda Eleştirel Düşünme Becerisi Kazandırılmasına } \\
\text { Yönelik Görüş }\end{array}$ & $\mathbf{n}$ & - & Ss. & $\mathbf{F}$ & $\mathbf{p}$ \\
\hline \multirow{3}{*}{ Ĕ̆itim Sistemi } & Evet & 63 & 42,90 & 8,94 & & \\
\hline & Kismen & 378 & 46,29 & 8,50 & 5,253 & $\mathbf{0 , 0 0 0 *}$ \\
\hline & Hayır & 147 & 49,45 & 9,32 & & \\
\hline \multirow{3}{*}{ Okulun İşlevleri } & Evet & 63 & 33,02 & 5,27 & & \\
\hline & Kismen & 378 & 34,71 & 5,30 & 10,999 & $\mathbf{0 , 0 0 0 *}$ \\
\hline & Hayır & 147 & 37,21 & 6,09 & & \\
\hline \multirow{3}{*}{ Özgürleşme } & Evet & 63 & 20,91 & 2,78 & & \\
\hline & Kismen & 378 & 20,47 & 3,01 & 0,776 & 0,431 \\
\hline & Hayı1r & 147 & 20,32 & 3,24 & & \\
\hline \multirow{3}{*}{$\begin{array}{c}\text { Eleştirel Pedagoji İlkeleri } \\
\text { Toplam }\end{array}$} & Evet & 63 & 96,84 & 10,35 & & \\
\hline & Kismen & 378 & 101,48 & 11,23 & 9,229 & $0,000 *$ \\
\hline & Hayır & 147 & 106,97 & 13,00 & & \\
\hline
\end{tabular}

$\mathrm{p}<0,05$

Tablo 3'te sınıf öğretmenlerinin okullarda öğrencilere eleştirel düşünme becerisinin kazandırılmasına yönelik görüşlerine göre eleştirel pedagoji ilkelerine katılımları gösterilmektedir. Tüm boyutlarda okullarda öğrencilere eleştirel düşünme becerisinin kazandırılmadığını düşünen sınıf öğretmenlerinin ortalama puanları, kazandırıldığını düşünen sınıf öğretmenleri ortalama puanlarından daha yüksektir ve öğretmenlerin çok az bir kısmı okullarda öğrencilere eleştirel düşünme becerisi kazandırıldığını düşünmektedir. Ayrıca Anova Testi sonuçlarına göre Eğitim Sistemi $(p=0,000<0,05)$ ve Okulun İşlevleri $(p=0,000<0,05)$ alt boyutu ve Eleştirel Pedagoji İlkeleri toplam puanda $(\mathrm{p}=0,000<0,05)$ anlamlı farklılık bulunmuştur. Bu anlamlı farklılı̆̆ın hangi gruplardan kaynaklandığını bulmak için varyansların homojenliğine göre Scheffe ya da Games-Howell Testi sonuçlarına bakılmıştır. Tablo 4'de Levene Testi sonuçlarına göre varyansların homojenliğine bakılmıştır.

Tablo 4. Sınıf öğretmenlerinin okullarda eleştirel düşünme becerisini kazandırılmasına yönelik görüşlerine göre eleştirel pedagoji ilkeleri Varyansların Homojenliği Testi

\begin{tabular}{|c|c|c|c|c|}
\hline Alt Boyutlar & Levene Testi & sd1 & sd2 & $\mathbf{P}$ \\
\hline Eğitim Sistemi & 1,481 & \multirow{4}{*}{2} & \multirow{4}{*}{585} & 0,228 \\
\hline Okulun İsslevi & 1,443 & & & 0,237 \\
\hline özgürleşme & 0,815 & & & 0,443 \\
\hline Eleştirel Pedagoji İlkeleri & 2,421 & & & 0,090 \\
\hline
\end{tabular}

$\mathrm{p}<0,05$

Tablo 4'deki Levene Testi sonuçlarına göre tüm boyutlarda varyanslar homojen dağılmaktadır ( $>>0,05)$. Buna göre söz konusu anlamlı farklılıkların tespiti için Scheffe Testi sonuçlarına bakılmıştır. Scheffe Testi sonuçları aşağıdaki tablolarda yer almaktadır.

Tablo 5. Sınıf öğretmenlerinin okullarda eleştirel düşünme becerisi kazandırılmasına yönelik görüşlerine göre eğitim sistemi alt boyutu Scheffe Testi sonuçları

\begin{tabular}{cccc}
\hline Eğitim Sistemi & Evet & Kısmen & Hayır \\
\hline Evet & - & $3,39^{*}$ & $6,55^{*}$ \\
Kısmen & $3,39^{*}$ & - & $3,15^{*}$ \\
Hayır & $6,55^{*}$ & $3,15^{*}$ & - \\
\hline
\end{tabular}

Tablo 5'te sınıf öğretmenlerinin okullarda öğrencilere eleştirel düşünme becerisi kazandırılmasına yönelik görüşlerine göre Eğitim Sistemi alt boyutundaki anlamlı farklılığın hangi gruplardan kaynaklandığına bakılmıştır. Buna göre okullarda öğrencilere eleştirel düşünme becerisinin kazandırılmadığını düşünen sınıf öğretmenleri 
$(-=49,45)$, kazandırıldığını $(-=42,90)$ ve kısmen kazandırıldığını düşünen sınıf öğretmenlerine $(-=46,29)$ göre eğitim sistemlerine daha eleştirel bakabilmektedir. $\mathrm{Bu}$ durum eğitim sistemlerine eleştirel bakış ile eleştirel düşünme becerisine eleştirel bakış arasındaki paralelliği göstermektedir. Öyle ki eğitim sistemlerine eleştirel bakan bireylerin, bu sistemde kazandırılan becerilere de eleştirel bakabilmeleri beklenen bir durumdur.

Tablo 6. Sınıf öğretmenlerinin okullarda eleştirel düşünme becerisi kazandırılmasına yönelik görüşlerine göre okulun işlevi alt boyutu Scheffe Testi sonuçları

\begin{tabular}{cccc}
\hline Okulun İşlevi & Evet & Kısmen & Hayır \\
\hline $\begin{array}{c}\text { Evet } \\
\text { Kismen } \\
\text { Hayır }\end{array}$ & - & - & $4,18^{*}$ \\
$2,50^{*}$ & - \\
\hline
\end{tabular}

Tablo 6'da sınıf öğretmenlerinin okullarda öğrencilere eleştirel düşünme becerisinin kazandırılmasına yönelik görüşlerine göre Okulun İşlevi alt boyutundaki anlamlı farklılığın hangi gruplardan kaynaklandığına bakılmıştır. Buna göre okullarda öğrencilere eleştirel düşünme becerisinin kazandırılmadığını düşünen sınıf öğretmenleri (--=37,21), kazandırıldığını $(--33,02)$ ya da kısmen kazandırıldığını düşünen sınıf öğretmeni adaylarına $(-=34,71)$ göre okulun işlevlerine daha eleştirel bakmaktadır. Bu durum okullarda eleştirel düşünme becerisinin kazandırılmadığını düşünen sınıf öğretmenlerinin aynı zamanda okulun işlevlerini de sorguladığı şeklinde yorumlanabilir.

Tablo 7. Sınıf öğretmenlerinin okullarda eleştirel düşünme becerisi kazandırılmasına yönelik görüşlerine göre eleştirel pedagoji ilkeleri katılımları Scheffe Testi sonuçları

\begin{tabular}{cccc}
\hline Eleştirel Pedagoji İlkeleri & Evet & Kismen & Hayır \\
\hline Evet & - & $4,64^{*}$ & $10,14^{*}$ \\
Kismen & $4,64^{*}$ & - & $5,50^{*}$ \\
Hayır & $10,14^{*}$ & $5,50^{*}$ & - \\
\hline
\end{tabular}

Tablo 7'de sınıf öğretmenlerinin okullarda eleştirel düşünme becerisinin kazandırılmasına yönelik görüşlerine göre eleştirel pedagoji ilkeleri katılımları arasındaki anlamlı farklılığın hangi gruptan kaynaklandığı gösterilmektedir. Buna göre okullarda eleştirel düşünme becerisinin kazandırılmadığını düşünen sınıf öğretmenleri $(--=106,97)$, kazandırıldığını $(-=96,84)$ ya da kısmen kazandırıldığını düşünen sınıf öğretmeni adaylarına $(-=101,48)$ göre eleştirel pedagoji ilkelerine daha fazla katılım göstermektedir. Bu durum Eğitim Sistemi ve Okulun İşlevi alt boyutunda olduğu gibi okullardaki eleştirel düşünme becerisine eleştirel bakan öğretmenlerin eleştirel pedagojiye daha yakın olduğunu göstermektedir. Tersten bakıldığında da eleştirel pedagoji ilkelerine katılan öğretmenlerin okullardaki eleştirel düşünme becerisini eleştirmesi beklenen bir durumdur.

\section{Üçüncü Alt Probleme İlişsin Bulgular ve Yorumlar}

Araştırmanın üçüncü alt problemi "Sınıf öğretmenlerinin eleştirel pedagoji ilkelerine katılımları ile mevcut ilkokul eğitim sistemine dair görüşleri arasında anlamlı bir farklılık bulunmakta mıdır?" şeklinde belirlenmiş̧ir. Buna göre Tablo 8'de sinıf öğretmenlerinin mevcut ilkokul eğitim sistemine yönelik görüşlerine göre eleştirel pedagoji ilkelerine katılımlarında anlamlı bir farklılık olup olmadığına bakılmıştır. Bununla ilgili Anova Testi sonuçları aşağıda yer almaktadır.

Tablo 8'de sınıf öğretmenlerinin mevcut ilkokul eğitim sistemine dair görüşlerine göre eleştirel pedagoji ilkelerine katılımları gösterilmektedir. Buna göre Eğitim Sistemi $(p=0,000<0,05)$ ve Okulun İşlevi $(p=0,000<0,05)$ alt boyutu ve Eleştirel Pedagoji İlkeleri toplam puanda $(\mathrm{p}=0,000<0,05)$ anlamlı farklıklar bulunmuştur. Ayrıca öğretmenlerin yarısından fazlası mevcut eğitim sistemine dair olumsuz görüşe sahip iken çok az bir kısım olumlu görüş bildirmiştir. Söz konusu anlamlı farklılığın hangi gruplardan kaynaklandığını tespit etmek için varyansların homojenliğine göre öncelikle Levene daha sonrada Scheffe ya da Games-Howell Testi sonuçlarına bakılmıştır. Tablo 9'da sınıf öğretmenlerinin eğitim sistemine yönelik görüşlerine göre Eleştirel Pedagoji İlkelerine katılımları varyanslarının homojenliği testi verilmiştir. 
Tablo 8. Sınıf öğretmenlerinin eğitim sistemine yönelik görüşlerine göre eleştirel pedagoji ilkeleri katılımı Anova

Testi sonuçları

\begin{tabular}{|c|c|c|c|c|c|c|}
\hline Alt Boyutlar & Eğitim Sistemine Dair Görüş & $\mathbf{n}$ & - & Ss. & $\mathbf{F}$ & $\mathbf{P}$ \\
\hline \multirow{5}{*}{ Eğitim Sistemi } & Çok Olumlu & 11 & 41,18 & 8,32 & \multirow{5}{*}{10,176} & \multirow{5}{*}{$0,000 *$} \\
\hline & Oldukça Olumlu & 19 & 40,31 & 6,33 & & \\
\hline & Kismen Olumlu & 200 & 45,10 & 8,64 & & \\
\hline & Pek Olumlu Değil & 218 & 46,00 & 8,15 & & \\
\hline & Hiç Olumlu Değil & 140 & 49,89 & 9,77 & & \\
\hline \multirow{5}{*}{ Okulun İşlevi } & Çok Olumlu & 11 & 31,82 & 4,26 & \multirow{5}{*}{9,519} & \multirow{5}{*}{$0,000 *$} \\
\hline & Oldukça Olumlu & 19 & 32,84 & 5,27 & & \\
\hline & Kismen Olumlu & 200 & 33,66 & 5,56 & & \\
\hline & Pek Olumlu Değil & 218 & 35,86 & 5,51 & & \\
\hline & Hiç Olumlu Değil & 140 & 36,77 & 5,44 & & \\
\hline \multirow{5}{*}{ Özgürleşme } & Çok Olumlu & 11 & 19,45 & 3,05 & \multirow{5}{*}{0,838} & \multirow{5}{*}{0,501} \\
\hline & Oldukça Olumlu & 19 & 21,37 & 2,17 & & \\
\hline & Kismen Olumlu & 200 & 20,54 & 3,16 & & \\
\hline & Pek Olumlu Değil & 218 & 20,50 & 2,86 & & \\
\hline & Hiç Olumlu Değil & 140 & 20,32 & 3,26 & & \\
\hline \multirow{5}{*}{ Eleştirel Pedagoji İlkeleri } & Çok Olumlu & 11 & 92,45 & 6,98 & \multirow{5}{*}{13,877} & \multirow{5}{*}{$0,000 *$} \\
\hline & Oldukça Olumlu & 19 & 94,52 & 7,05 & & \\
\hline & Kismen Olumlu & 200 & 99,30 & 11,60 & & \\
\hline & Pek Olumlu Değil & 218 & 103,36 & 11,19 & & \\
\hline & Hiç Olumlu Değil & 140 & 106,98 & 12,47 & & \\
\hline
\end{tabular}

$\mathrm{p}<0,05$

Tablo 9. Sınıf öğretmenlerinin eğitim sistemlerine yönelik görüşlerine göre eleştirel pedagoji ilkeleri katılımı Varyansların Homojenliği Testi

\begin{tabular}{|c|c|c|c|c|}
\hline Alt Boyutlar & Levene Testi & sd1 & sd2 & $\mathbf{P}$ \\
\hline Eğitim Sistemi & 2,917 & & & 0,021 \\
\hline Okulun İşlevi & 0,201 & 4 & 583 & 0,938 \\
\hline Özgürleşme & 0,946 & 4 & 583 & 0,437 \\
\hline Eleștirel Pedagoji İlkeleri Toplam & 2,788 & & & 0,026 \\
\hline
\end{tabular}

Tablo 9'da Levene Testi sonuçlarına göre sınıf öğretmenlerinin eğitim sistemine yönelik görüşlerine göre Eleştirel Pedagoji İlkeleri katılımlarını varyansların homojenliği testi yer almaktadır. Buna göre Eğitim Sistemi alt boyutu $(\mathrm{p}=0,021<0,05)$ ve Eleştirel Pedagoji İlkeleri toplam puanı $(\mathrm{p}=0,026<0,05)$ heterojen bir yapıda iken Okulun İşlevi $(\mathrm{p}=0,938>0,05)$ ve Özgürleşme alt boyutu $(\mathrm{p}=0,437>0,05)$ homojen bir yap1 sergilemektedir. $\mathrm{Bu}$ durumda heterojen yapılar için Games-Howell Testi sonuçları; homojen yapılar için ise Scheffe Testi sonuçları dikkate alınmaktadır. Aşağıda Games-Howell ve Scheffe Testi sonuçları yer almaktadır.

Tablo 10. Sınıf öğretmenlerinin eğitim sistemine yönelik görüşlerine göre eğitim sistemi alt boyutu Games-Howell testi sonuçları

\begin{tabular}{cccccc}
\hline Ĕgitim Sistemi & Çok olumlu & Oldukça olumlu & Kısmen olumlu & Pek olumlu değil & Hiç olumlu değil \\
\hline Çok olumlu & - & & & & $8,71^{*}$ \\
Oldukça olumlu & & - & $4,79^{*}$ & $6,69^{*}$ & $9,58^{*}$ \\
Kısmen olumlu & & $4,79^{*}$ & - & - & $4,79^{*}$ \\
Pek olumlu değil & & $6,69^{*}$ & $4,79^{*}$ & $2,89^{*}$ & $2,89^{*}$ \\
Hiç olumlu değil & $8,71^{*}$ & $9,58^{*}$ & & - \\
\hline
\end{tabular}

Tablo 10'da sınıf öğretmenlerinin mevcut ilkokul eğitim sistemine yönelik görüşlerine göre Eğitim Sistemi alt boyutundaki anlamlı farklılı̆̆ın hangi gruplardan kaynaklandığını gösteren Games-Howell Testi sonuçları yer almaktadır. Buna göre eğitim sistemine yönelik hiç olumlu görüş bildirmeyen sınıf öğretmenleri $(-=49,89)$, çok olumlu görüş bildiren (-- $=41,18)$, oldukça olumlu görüş bildiren $(-=40,31)$, kismen olumlu görüş bildiren $(-=45,10)$ ve pek olumlu görüş bildirmeyen $(-=46,00)$ sınıf öğretmenlerine göre eğitim sistemlerine daha eleştirel bakabilmektedir. $\mathrm{Bu}$ durum mevcut ilkokul eğitim sistemine dair olumsuz görüşe sahip sınıf öğretmenlerinin eğitim sistemlerine de eleştirel baktığını göstermektedir. Aynı zamanda söz konusu durum, Eleştirel Pedagoji İlkeleri ölçeğinin Eğitim Sistemi alt boyutunu da destekler niteliktedir. Zira eğitim sistemine eleştirel bakan bireyler Eğitim Sistemi alt 
boyutuna da katılım göstermektedir. Buna göre öğretmenlerin büyük bir çoğunluğu mevcut ilkokul eğitim sistemine dair olumsuz bir görüşe sahip ve bu görüş Eğitim Sistemi alt boyutuna katılımı da doğrudan etkilemektedir.

Tablo 11. Sınıf öğretmenlerinin eğitim sistemine yönelik görüşlerine göre okulun işlevi alt boyutu Scheffe Testi sonuçları

\begin{tabular}{cccccc}
\hline Okulun İşlevi & Çok olumlu & Oldukça olumlu & Kısmen olumlu & Pek olumlu değil & Hiç olumlu değil \\
\hline Çok olumlu & - & & & & \\
Oldukça olumlu & & - & - & $2,20^{*}$ & $3,11^{*}$ \\
Kısmen olumlu & & & $2,20^{*}$ & - & - \\
Pek olumlu değil & & & $3,11^{*}$ & & \\
Hiç olumlu değil & & & & \\
\hline
\end{tabular}

Tablo 11'de sınıf öğretmenlerinin mevcut ilkokul eğitim sistemine yönelik görüşlerine göre Okulun İşlevi alt boyutu arasındaki anlamlı farklılığın hangi gruptan kaynaklandığını gösteren Scheffe Testi sonuçları yer almaktadır. Buna göre eğitim sistemine dair kısmen olumlu görüş bildiren sinıf öğretmenleri $(-=33,66)$, pek olumlu görüş bildirmeyen $(-=35,86)$ ve hiç olumlu görüş bildirmeyen sınıf öğretmenlerine $(-=36,77)$ göre okulun işlevlerini daha az sorgulamaktadır. Bu durum, mevcut ilkokul eğitim sistemine dair olumlu görüşe sahip bireylerin okulun işlevlerini daha az sorguladığ 1 şeklinde yorumlanabilir.

Tablo 12. Sınıf öğretmenlerinin eğitim sistemine yönelik görüşlerine göre eleştirel pedagoji ilkeleri toplam puan

Games-Howell Testi sonuçları

\begin{tabular}{cccccc}
\hline Eleştirel Pedagoji İlkeleri & Çok olumlu & Oldukça olumlu & Kısmen olumlu & Pek olumlu değil & Hiç olumlu değil \\
\hline Çok olumlu & - & & & $10,91^{*}$ & $14,53^{*}$ \\
Oldukça olumlu & & - & & $8,84^{*}$ & $12,46^{*}$ \\
Kısmen olumlu & & & - & $4,06^{*}$ & $7,68^{*}$ \\
Pek olumlu değil & $10,91^{*}$ & $8,84^{*}$ & $4,06^{*}$ & - & $3,62^{*}$ \\
Hiç olumlu değil & $14,53^{*}$ & $12,46^{*}$ & $7,68^{*}$ & $3,62^{*}$ & - \\
\hline
\end{tabular}

Tablo 12'de sınıf öğretmenlerinin mevcut ilkokul eğitim sistemine yönelik görüşleri ile eleştirel pedagoji ilkeleri katılımları arasındaki anlamlı farklılığın hangi gruptan kaynaklandığını gösteren Games-Howell Testi sonuçları yer almaktadır. Buna göre söz konusu farklılık Eğitim Sistemi ve Okulun İşlevi alt boyutunda olduğu gibi eğitim sistemine dair olumsuz görüşe sahip olan sınıf öğretmenleri ile olumlu görüşe sahip olan sınıf öğretmenleri arasında, olumsuz görüşe sahip olan sınıf öğretmenleri lehine olmaktadır. Bu durum eğitim sistemine dair olumsuz görüşe sahip sınıf öğretmenlerinin eleştirel pedagoji ilkelerine daha fazla katıldıkları şeklinde yorumlanabilir. Buna göre diğer alt boyutlarda olduğu gibi mevcut ilkokul eğitim sistemine dair eleştirel bakış, aynı zamanda eleştirel pedagoji ilkelerine de katılımı göstermektedir.

\section{Sonuç}

Sınıf öğretmenlerinin cinsiyetlerine göre Okulun İşlevi alt boyutu ve Eleştirel Pedagoji İlkeleri toplam puanda anlamlı farklılık vardır. Söz konusu farklılık her iki boyutta da erkek öğretmenler lehinedir. Ayrıca sınıf öğretmenlerinin Eğitim Sistemi, Okulun İşlevi ve Eleştirel Pedagoji İlkeleri toplam puanları orta düzeyde; Özgürleşme alt boyutu ise yüksek düzeyde bulunmuştur.

Sınıf öğretmenlerinin, okullarda öğrencilere eleştirel düşünme becerisi kazandırılmasına yönelik görüşlerine göre tüm boyutlarda okullarda öğrencilere eleştirel düşünme becerisinin kazandırılmadığını düşünen sınıf öğretmenlerinin ortalama puanları, kazandırıldığını düşünen öğretmen adayları ortalama puanlarından daha yüksektir ve öğretmenlerin çok az bir kısmı okullarda öğrencilere eleştirel düşünme becerisi kazandırıldığını düşünmektedir. Ayrıca Eğitim Sistemi ve Okulun İşlevleri Alt boyutu ve Eleştirel Pedagoji İlkeleri toplam puanda anlamlı farklılık vardır. Söz konusu farklılıklar şu şekildedir:

1. Okullarda öğrencilere eleştirel düşünme becerisinin kazandırılmadığını düşünen sınıf öğretmenleri, kazandırıldığını ve kısmen kazandırıldığını düşünen sınıf öğretmenlerine göre eğitim sistemlerine daha eleştirel bakmaktadır.

2. Okullarda öğrencilere eleştirel düşünme becerisinin kazandırılmadığını düşünen sınıf öğretmenleri, kazandırıldığını ya da kısmen kazandırıldığını düşünen sınıf öğretmenlerine göre okulun işlevlerine daha eleştirel bakmaktadır.

3. Okullarda eleştirel düşünme becerisinin kazandırılmadığını düşünen sınıf öğretmenleri, kazandırıldığını ya da kısmen kazandırıldığını düşünen sınıf öğretmenlerine göre eleştirel pedagoji ilkelerine daha fazla katılım göstermektedir. 
Sınıf öğretmenlerinin büyük bir çoğunluğu genel olarak mevcut ilkokul eğitim sistemlerine dair olumsuz görüş bildirmişlerdir. Ayrıca sınıf öğretmenlerinin mevcut ilkokul eğitim sistemine dair görüşlerine göre Eğitim Sistemi ve Okulun İşlevi alt boyutu ve Eleştirel Pedagoji İlkeleri toplam puanda anlamlı farklıklar vardır. Bu farklılıklar şu şekildedir:

1. Mevcut eğitim sistemine yönelik hiç olumlu görüş bildirmeyen sınıf öğretmenleri, çok olumlu görüş bildiren, oldukça olumlu görüş bildiren, kısmen olumlu görüş bildiren ve pek olumlu görüş bildirmeyen sinıf öğretmenlerine göre eğitim sistemlerine daha eleştirel bakmaktadır.

2. Mevcut eğitim sistemine dair kısmen olumlu görüş bildiren sınıf öğretmenleri, pek olumlu görüş bildirmeyen ve hiç olumlu görüş bildirmeyen sınıf öğretmenlerine göre okulun işlevlerini daha az sorgulamaktadır.

3. Eğitim Sistemi ve Okulun İşlevi alt boyutunda olduğu gibi mevcut eğitim sistemine dair olumsuz görüşe sahip olan sınıf öğretmenleri ile olumlu görüşe sahip olan sınıf öğretmenleri arasında, olumsuz görüşe sahip olan sınıf öğretmenleri lehine anlamlı farklılık vardır. Buna göre genel olarak mevcut eğitim sistemlerine dair olumsuz görüşe sahip olan sınıf öğretmenleri eleştirel pedagoji ilkelerine daha fazla katılım göstermektedir.

\section{Tartışma}

Araştırma sonuçlarına göre eleştirel pedagoji ilkelerine katılım orta düzeyde bulunmuştur. Bu sonuç Yılmaz \& Altınkurt (2011), Şahin, Demir \& Arcagök (2016), Sarıgöz \& Özkara (2015) ve Aslan \& Kozikoğlu'nun (2015) araştırmaları ile benzerlik göstermektedir. Eleştirel düşünme üzerine yapılan çalışmalarda olduğu gibi eleştirel pedagoji algısı da genel olarak düşük ya da orta düzeydedir. Bu durum, bireylerin eleştiri bilincinin yükseltilmesinde daha fazla çabaya ihtiyaç olduğunu göstermektedir. Ayrıca söz konusu bilinç yükseltme çabası uzun soluklu ve sistemli bir çalı̧̧mayı gerektirmektedir.

Cinsiyete göre, sınıf öğretmenlerinde erkekler kadınlara göre eleştirel pedagoji ilkelerine daha fazla katılmaktadırlar. Yılmaz \& Altınkurt (2011) ve Aslan \& Kozikoğlu (2015) araştırmalarında, sınıf öğretmeni adayı erkeklerin eleştirel pedagoji ilkelerine daha fazla katılım gösterdiğini bulmuştur. Ancak Balcı'nın (2016) sınıf öğretmeni adayları üzerinde yaptığı çalışmada ise cinsiyete göre anlamlı bir farklılık olmamasına rağmen kadın öğretmen adaylarının erkek öğretmen adaylarına göre eleştirel pedagoji ilkelerine daha fazla katılım gösterdiğ bulunmuştur. Yine Yılmaz'ın (2009) ilkokul öğretmenleri üzerinde yaptığı araştırmada cinsiyete göre anlamlı bir farklılık olmamasına rağmen erkek öğretmenlerin katılımı daha yüksek bulunmuştur. Bu araştırmada da sınıf öğretmenlerinde erkekler lehine bir farklılık bulunmuştur. Bu durum Yilmaz (2009), Y1lmaz \& Altınkurt (2011), Aslan \& Kozikoğlu (2015) çalışmaları ile paralellik gösterirken; Balcı'nın (2016) çalışmasında kadınların sınıf öğretmeni adayı iken eleştirel pedagoji ilkelerine gösterdikleri yüksek katılım, mesleğe devam eden hem cinslerinde daha düşük bulunmuştur. Bunda toplumsal cinsiyet rolleri başta olmak üzere birçok etmen söz konusu olmaktadır. Zira kadın sınıf öğretmeni adaylarının, mesleğe başladıktan sonra toplumsal roller nedeniyle bakış açılarında değişiklik olduğu düşünülebilir. Yine kadın öğretmen adaylarının eleştirel pedagoji ilkelerine düşük katılımı, sadece cinsiyet değişkenine indirgenemeyecek derecede derin bir mesele olması nedeniyle ayrıca incelenmesi gereken bir konudur.

Okullarda öğrencilere eleştirel düşünme becerisinin kazandırılmasına yönelik görüşlere göre, eleştirel pedagoji ilkelerine katılımda, okullarda öğrencilere eleştirel düşünme becerisinin kazandırılmadığının düşünenler eleştirel pedagoji ilkelerine daha fazla katılım göstermektedir. Ayrıca okullarda öğrencilere eleştirel düşünme becerisi kazandırılmadığını düşünen sınıf öğretmenleri kazandırıldığını düşünen sınıf öğretmenlerine göre eleştirel pedagoji ilkelerine daha fazla katılım göstermektedir. $\mathrm{Bu}$ durum beklenen bir durumdur ve aynı zamanda "Eleştirel Düşünmenin Eleştirisi”"ni de destekler niteliktedir. Zira bağlamında koparılmış bir eleştiri bilincinin gerçek anlamada eleştirel bireyler yetiştirmede etkisiz olduğu düşünülmektedir. Bu durumu katılımcıların büyük çoğunluğu da desteklemekte ve okullarda öğrencilere eleştirel düşünme becerisinin kazandırılmadığını düşünmektedirler. Ayrıca eleştirel düşünmenin eleştirisini yapan katılımcılar eleştirel pedagojiye daha yakındırlar. Kesik \& Bayram'ın (2015) araştırmasında da öğretmenlerin eğitim sistemini eleştirel bulmadıkları sonucuna ulaşılmıştır. Ayrıca Kocabaş, Balcı, Erbil \& Erdoğan'ın (2015) eleştirel pedagoji ve eleştirel düşünme arasındaki ilişkiyi inceledikleri çalışmada da iki yapı arasında herhangi bir ilişki bulunamamıştır. Bu durum okullarda verilen eleştirel düşünme becerisinin bağlamından kopuk olduğu şeklinde yorumlanmaktadır. Söz konusu araştırmalar, bu araştırmayı da destekler niteliktedir. Bu nedenle eleştirel düşünme becerisinin öğrencilere kazandırılmasında eleştirel pedagojiden daha fazla yararlanılmalıdır.

Mevcut ilkokul eğitim sistemine dair görüşe göre, eleştirel pedagoji ilkelerine katılım arasında anlamlı farlılık bulunmuştur. Buna göre mevcut eğitim sistemine dair görüşü olumsuz yönde olan katılımcılar olumlu yönde olan katılımcılara göre eleştirel pedagoji ilkelerine daha fazla katılım göstermektedirler. Bu durum mevcut eğitim sistemine eleştirel bakan bireylerin, eleştirel pedagojiye daha fazla katılım göstermeleri açısından araştırma sonuçlarını destekler niteliktedir. Zira eleştirel pedagojide esas olan eğitim sistemlerine eleştirel bir bakış getirmektir. Kesik \& Bayram'ın (2015) araştırmasında da öğretmenlerin mevcut eğitim sistemini çoğulcu, eleştirel, özgürleştirici, demokratik, adil ve 
dönüştürücü bulmadıkları sonucuna ulaşılmıştır. Moss \& Lee (2010) ise eleştirel pedagoji eğitiminin, eğitim sorunlarına bakışı anlamlı derecede değiştirdiğini bulmuştur. Yine Edwards Jr. (2009), eleştirel pedagoji ve demokrasi arasındaki ilişkiden söz etmektedir. Söz konusu paralellikler göz önüne alındığında, eleştirel pedagojinin mevcut eğitim sistemlerine yönelik eleştirileri daha fazla dikkate alınmalıdır. Eğer eğitimde köklü değişimler isteniyorsa buna uygun radikal çözüm önerileri üzerinde durmak gerekmektedir.

Öğrencilere teknik bir beceri olarak kazandırılmaya çalışılan eleştirel düşünme becerisi, eğitim sistemini daha eleştirel yapmayacağı gibi öğrencilerin de eleştirel bireyler olmasını sağlamada yeterli olmayacaktır. Kavramın kendisi teknik bir beceriye indirgendiğinde özünden uzaklaşmakta ve anlamını yitirmektedir. Passmore'un (1991) da belirttiği üzere bir ehliyet kursunda sürücü adaylarına kazandırılması beklenen becerilerle düşünme becerilerini bir tutmak mümkün değildir. Sürücü adayları ehliyet sınavında başarılı olabilirler ancak bu onların iyi birer sürücü olduğunu tek başına kanttlayamaz. Benzer şekilde öğrencilere okulda ünitelerde eleştirel düşünme becerilerinin kazandırıldığı düşünülebilir ancak bu onların eleştirel bireyler olduğunu tek başına kanıtlayamaz. Kaldı ki öğretmen ve yöneticilerin de ne kadar eleştirel oldukları ayrı bir tartışmayı gerektirmektedir. Yıldız'ın (2013) da belirttiği üzere öğretmenliğin dönüşümü, entelektüel öğretmenden sınava hazırlayıcı tekniker öğretmene doğru evrilmektedir. Bu nedenle içeriği boşaltılmış bir eleştirel düşünme ve buna bağlı eğitim sistemleri yerine eleştirel düşünmenin sistematik olarak tartışıldığı eleştirel teori ve eleştirel pedagoji literatüründen daha fazla yararlanılması gerekmektedir.

\section{Öneriler}

1. 21. yüzyıl eğitim felsefesi olarak eleştirel eğitim felsefesi ve buna bağlı olarak eleştirel pedagoji ile ilgili daha fazla ve derinlemesine araştırmalar yapılmalı ve bunlar mevcut eğitim sistemiyle kaynaştırılmalıdır.

2. Türkiye'de eleştirel düşünme ve eleştirel pedagoji algısının yükseltilmesine yönelik adımlar atılmalı ve eleştirel teori, eleştirel pedagoji ve eleştirel düşünme arasındaki ilişki ortaya konulmalı; eleştirel düşünme eğitimi, eleştirel teori ve eleştirel pedagojiye göre yeniden şekillendirilmelidir.

3. Dünyadaki eleştirel pedagoji uygulamaları incelenerek Türkiye'de uygulanabilirliği tartışılmalıdır.

4. Sınıf öğretmenlerinin mevcut ilkokul eğitim sistemine dair olumsuz görüşlerini değiş̧irebilecekleri, katılımcı bir anlayış ile mevcut eğitim sistemi tekrardan gözden geçirilmelidir.

5. Öğretmen adaylarının eğitim sistemlerine eleştirel bakabilmelerinin sağlanması için eğitim fakültelerine Eleştirel Pedagoji dersleri konulmalıdır. 


\section{Kaynaklar / References}

Apple, M. W. (2006). Ĕgitim ve İktidar (Çev.: E. Bulut). İstanbul: Kalkedon Yayınları.

Apple, M. W. (2009). Müfredatın ve Eğitimin Yeniden Yapılandırılması / Neo-liberalizmin ve Yeni-muhafazakarlığın Gündemi. Eleştirel Pedagoji Söyleşileri (Çev. E. Ç. Babaoğlu). İstanbul: Kalkedon Yayınları.

Aslan, M. \& Kozikoğlu, İ. (2015). Pedagojik Formasyon Eğitim Alan Öğretmen Adaylarının Eleştirel Pedagojiye İlişkin Görüşleri. Abant İzzet Baysal Üniversitesi Eğitim Fakültesi Dergisi. 15 (1), 1-14.

Bakioğlu, A. \& Hesapçığlu, M. (1997). Düşünmeyi Öğretmekte Öğretmen ve Okul Yöneticisinin Rolü: Düşünmek! M.Ü. Atatürk Ĕ̆itim Fakültesi Ĕ̆itim Bilimleri Dergisi. 9, 49-78.

Balcı, A. T. (2016). Eleştirel Pedagoji Algısının Bazı Değişkenler Açısından Değerlendirilmesi. Yayınlanmamış yüksek lisans tezi, Dokuz Eylül Üniversitesi, İzmir.

Balcı, A. T. \& Kocabaş, A. (2018). Türkiye'de Eleştirel Düşünme Üzerine Yapılan Doktora Tezlerinin İçerik Analizi. V. International Eurasian Educational Research Congress Conference Proceedings. 2-5 May1s 2018 (ss. 147-149). Ankara: An1 Yayınc1lik.

Balkız, B. (2004). Frankfurt Okulu ve Eleştirel Teori: Sosyolojik Pozitivizmin Eleştirisi. Sosyoloji Dergisi. 12 (13), $135-158$.

Büyüköztürk, Ş., Çakmak, E. K., Akgün, Ö. E., Karadeniz, Ş. \& Demirel, F. (2013). Bilimsel Araştırma Yöntemleri. (15. Baskı). Ankara: Pegem Akademi Yayıncılık.

Cevizci, A. (2014). Ĕ̌itim Felsefesi. İstanbul: Say Yayınları.

Durdu, Z. (2006). Frankfurt Okulu’nun Sosyal Bilim Anlayışı. Sosyoloji Dergisi. 15, 15-32.

Edwards Jr, D. B. (2009). Critical Pedagogy and Democratic Education: Possibilities for Cross-pollination. The Urban Review, 42(3), 221-242.

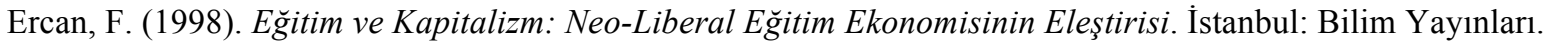

Freire, P. (2003). Ezilenlerin Pedagojisi. (Çev. D. Hattatoğlu ve E. Özbek). İstanbul: Ayrıntı Yayınları.

Freire, P. (2014). Yüreğin Pedagojisi. (Çev. Ö. Orhangazi). İstanbul: Ayrıntı Yayınları.

Giroux, H. A. (2009). Dil/kültürel İncelemeler Alanında Eleştirel Pedagojinin Bir Rolü Var mıdır? Eleştirel Pedagoji Söyleşileri (Çev. E. Ç. Babaoğlu). İstanbul: Kalkedon Yayınları.

Gök, F. (Ed.). (1999). 75 Yılda İnsan Yetiştirme Eğitim ve Devlet. Fatma G. 75 Yılda Eğitim. İstanbul: Tarih Vakfı Yayınları.

Gramsci, A. (2014). Hapishane Defterleri (Çev. A. Cemgil). İstanbul: Belge Yayınları.

Gutek, G. L. (2006). Eğitime Felsefi ve İdeolojik Yaklaşımlar (Çev. N. Kale). Ankara: Ütopya Yayınevi.

Gülenç, K. (2010). Eleştiri, Toplum ve Bilim: Frankfurt Okulu Üzerine Bir İnceleme. Yayınlanmamış Doktora Tezi, Hacettepe Üniversitesi Sosyal Bilimler Enstitüsü, Ankara.

İnal, K. (2014). Çocuk ve Demokrasi. İstanbul: Ayrıntı Yayınları.

Karasar, N. (2013). Bilimsel Araştırma Yöntemi. (25. Baskı). Ankara: Nobel Akademik Yayıncılık.

Kesik, F. \& Bayram, A. (2015). Eğitim Sisteminin Eleştirel Pedagoji Perspektifinden Bir Değerlendirmesi. Mersin Üniversitesi Ĕ̈itim Fakültesi Dergisi. 11 (3), 901-921.

Kocabaş, A., Balcı, A. T., Erbil, D. G. \& Erdoğan, F. (2015). Öğretmen Adaylarının Eleştirel Düşünme ve Eleştirel Pedagoji İlkeleri Düzeyleri Arasındaki İlişkinin Değerlendirilmesi. 14. Uluslararası Katılımlı Sınıf Öğretmenliği Ĕ̆itimi Sempozyumu, Bartın Üniversitesi, Bartın.

McLaren, P. (2011). Okullarda Yaşam - Eleştirel Pedagojiye Giriş (Çev. Ed. M. Y. Eryaman ve H. Arslan). Ankara: Anı Yayıncilik. 
Moss, G. \& Lee, C. (2010). A Critical Analysis of Philosophies of Education and INTASC Standarts in Teacher Preparation. International Journal of Critical Pedagogy. 3 (2), 36-46.

Passeron, J. C. ve Bourdieu, P. (2015). Yeniden Üretim. (Çev.: A. Sümer, Ö. Akkaya ve L. Ünsaldı). Ankara: Heretik Yayıncılık.

Passmore, J. (1991). Eleştirel Olmayı Öğretme Üstüne. (Çev. H. Ünder). Ankara Üniversitesi Eğitim Bilimleri Fakültesi Dergisi. 24(2), 629-648. (Orijinal çalışmanın yayın tarihi 1967).

Sağıroğlu, N. A. (2008). Özgürleştirici Bir Eğitim Arayışı: Eleştirel Pedagoji Okulu. Eğitim Bilim Toplum Dergisi. 6 (24), 50-61.

Sarıgöz, O. ve Özkara, Y. (2015). Öğretmen Adaylarının Eleştirel Pedagoji ve İlkeleri Hakkındaki Görüşlerinin Bazı Değişkenler Açısından İncelenmesi. Uluslararası Sosyal Araştırmalar Dergisi. 8 (39), 710-716.

Şahin, Ç., Demir, M. K. \& Arcagök, S. (2016). Öğretmen Adaylarının Eleştirel Pedagoji İlkelerine Yönelik Yaklaşımlarının Çeşitli Değişkenler Açısından İncelenmesi. Erzincan Üniversitesi Eğitim Fakültesi Dergisi 18 (2), 1187-1205.

Tezcan, M. (2013). Sosyolojik Kuramlarda Eğitim. Ankara: Anı Yayıncılık.

Yıldırım, A. (2013). Eleştirel Pedagoji - Paulo Freire ve Ivan Illich’in Eğitim Anlayışı Üzerine (3. Baskı). Ankara: Anı Yayıncilik.

Yıldız, A. (2013). Türkiye’de Öğretmenlik Mesleğinin Dönüşümü: İdealist Öğretmenden Sınava Hazırlayıı Teknisyen Öğretmene. Eleştirel Pedagoji Dergisi, 27, 43-50.

Yilmaz, K. (2009). Elementary School Teachers' View About The Critical Pedagogy. The Asia-Pacific Education Researcher. 18 (1), 139-149.

Yılmaz, K. \& Altınkurt Y. (2011). Öğretmen Adaylarının Eleştirel Pedagoji İle İlgili Görüşleri. Ahi Evran Üniversitesi Eğitim Fakültesi Dergisi. 12 (3), 195-213. 